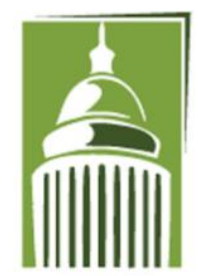

ARF

\section{Global Proceedings Repository \\ American Research Foundation}

ISSN 2476-017X

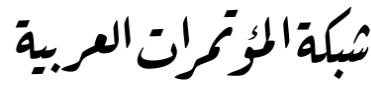

http://arab.kmshare.net/

Available online at http://proceedings.sriweb.org

The 10th International Scientific Conference

Under the Title

"Geophysical, Social, Human and Natural Challenges in a Changing Environment"

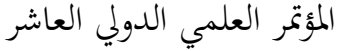

$$
\begin{aligned}
& \text { تحت عنوان "التحديات الجيوفيزيائية والاجتماعية والانسانية والطبيعية في بيئة متغيرة" } \\
& 25 \text { - } 26 \text { يوليو - تموز } 2019 \text { - اسطنبول - تركيا }
\end{aligned}
$$

http://kmshare.net/isac2019/

\title{
Pathological Changes Of Phenobarbital Injection In Local goats
}

\author{
Methaq A.Abd alsammed ${ }^{\mathrm{a}}$, Zainab W.Kuder ${ }^{\mathrm{b}}$ \\ a ,b Basra University, Veterinary Collage, pathology department
}

methaq2.rada@gmail.com

$\&$

Pathovet.basra2015@gmail.com

\begin{abstract}
The effect to phenobarbital pathological pre treatment in the Calotropisprocera local male goats was examined. The goats receiving phenobarbital sodiumat daily injection doses of $65 \mathrm{mg} / \mathrm{kg} /$ day for 90 days, exhibited marked depression, lateral deviation of the head and neck, dyspnea and frequent urination and histopathological, they showed centri lobular hepato cellular necrosis and fatty cytoplasmic vaccuolation of the hepatocytes with central vein with fibrosis in liver ,lung showed emphysema of alveoli and dilated of blood vessels and hyperplasia of bronchiole ,kidney showed degeneration of epithelial cells lining of renal tubules, while rumen undergo vacuolated of mucosal layer, degenerative changes in spleen and thickening in the capsule of testis with suppression of seminiferous tubules.
\end{abstract}

Key word:- Pathology ,phenobarbital, ,liver ,spleen, , rumen, lung, testis 


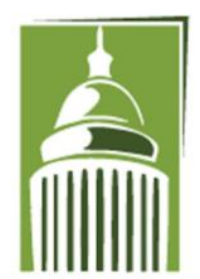

ARF

\section{Global Proceedings Repository \\ American Research Foundation}

ISSN 2476-017X

Available online at http://proceedings.sriweb.org

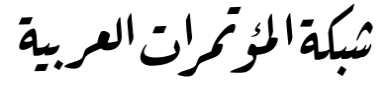

http://arab.kmshare.net/

\section{Introduction}

The Phenobarbital is a barbiturate and it is the most widely used anticonvulsant worldwide [1]. It is also used to control epilepsy (seizures) and as a sedative to relieveanxiety. It is used for short-term treatment of insomnia to help to sleep, [2] It was used totreat neonatal jaundice by increasing liver metabolism and thus lowering bilirubin levels.[3]..Phenobarbital has an oral bioavailability of about 90\%. Peak plasma concentrations are reached eight to 12 hours after oral administration. It is one of the longest-acting barbiturates available - it remains in the body for a very long time (half-life of two to seven days) and has very low protein binding (20 to 45\%). Phenobarbital is metabolized by the liver.

Phenobarbital is a known inducer of microsomal enzymes (CytochromeP-450 (CYP),NADPHcytochrome P-450 reductase, NADPHoxidase, glutathione -Svt.ransfer-ase) which are responsible for the metabolic breakdown of a large number of endogenous and exogenous chemical compounds $[4,5,6]$. It is reported that Phenobarbital decrease the toxicity of some organophosphate as aresult of an increase in paraoxonase activity .In addition, a number of xenobiotics increase serum AST and ALT activities and are used as markers of liver toxicity and it is reported that Phenobarbital treatment increased these activities and protein levels in the liver [7].phenobarbitone (BAN) is a long-acting barbiturate and the most widely used anti-seizure medication globally[8]. It has sedative properties, but as with other barbiturates, benzodiazepines are more commonly used for this purpose.[9].

Phenobarbital is removed from the body by the liver and should be used with extreme caution in animals with liver disease at higher dose, also Phenobarbital decreases the ability of the lung to function properly. and should be used very carefully in animals who have lung disease or lung condition. such as dogs and cats use panting from the lungs to cool themselves as they cannot sweat .Depressing breathing cannot only cause oxygen shortage ,but can cause animal to overheat[3].

\subsection{Veterinary uses:}

Phenobarbital is one of the initial drugs of choice to treat epilepsy in dogs, and is the initial drug of choice to treat epilepsy in cats. ${ }^{[10]}$ It is also used to treat feline hyperesthesia syndrome in cats when anti obsessional therapies prove ineffective. [11] It may also be used to treat seizures in horses when benzodiazepine treatment has failed or is contraindicated. ${ }^{[12]}$ 


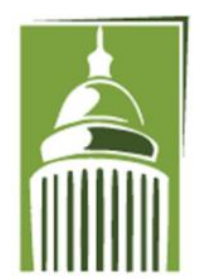

ARF

\section{Global Proceedings Repository \\ American Research Foundation}

ISSN 2476-017X

Available online at http://proceedings.sriweb.org

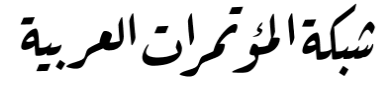

http://arab.kmshare.net/

\section{MATERIALS AND METHODS}

\subsection{Animals:}

Sixteen healthy adult local male goats were selected from a herd animals, aged between nine months to one year and weight ranged between $25-35 \mathrm{Kg}$.. All goats were treated against internal and external parasites by using Ivermectin (Kela-Belgium)at dose of $200 \mu \mathrm{g} / \mathrm{Kg}$ B.W.subcutaneously with Rafoxind 3\% at a dose $1.25 \mathrm{mg} / \mathrm{kg} \mathrm{B}$.W. The animals were fasted for 36 hours of food and 12 hours water with held preoperatively. (Ehasanetal,2015). were given by the oral route phenobarbital only at $65 \mathrm{mg} / \mathrm{kg} / \mathrm{day}$ for 90days

\subsection{Histopathological Technique}

The speciment were taken from animals after necropcy on the 45 and 90 days, these include ,( testis, spleen,lung, rumen, and liver). Then fixing in nutural buffered formalin (10\%), dehydration was done by passing thespeciments in increasing concentration of ethanol, infiltrated 3 times with xylene orchloroform and embedded in baraffin. 5-6 micrones and stained with Hematoxyline - Eosin.and finally examined under light microscope.

\section{Results:}

\subsection{Clinical finding:}

Goats receivingphenobarbital sodiumat daily oral doses of $65 \mathrm{mg} / \mathrm{kg} / \mathrm{day}$ for 90 days, exhibited marked depression, lateral deviation ofthe head and neck, dyspnea and frequent urination.

\subsection{Necropsy finding:}

Necropsy revealed varying degrees of jaundice of the subcutaneous, omental and mesentric fat including serous and mucous membranes. The livers were enlarged and firm, mottled and icteric with distended gall bladders.

Liver pathology was further confirmed by presence of necropsy where evidence of liver changes was shown. The livers were consistently slightly enlarged and containing marked thickened bile duct, and the kidneys were darker than normal. Cholangitis and mild bile retention were also observed.

\subsection{Histopathological findings:}

After examined the slides under the microscope we observed histological changes in some organs Ingoats,testis showed degeneration ofthe seminiferous tubules with thickening of capsule and suppression of spermatogenesis(Fig.1,2). lung showed emphysema of alveoli and dilated of blood vessels and hyperplasia of bronchiole (fig.3,4).In liver showed dilation of sinusoid sub capsular fatty degeneration hypertrophy of hepatic cells ,excessive fibrosis in portal area with narrowing the lumen of portal duct (fig.5,6). 


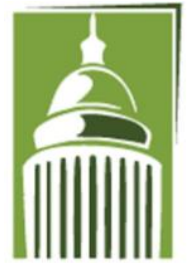

A R F

\section{Global Proceedings Repository}

American Research Foundation

ISSN 2476-017X
شبكة المؤمرات العر.بة

http://arab.kmshare.net/

Available online at http://proceedings.sriweb.org

rumen showed degenerative changes of epithelial cells,)and edematous fluid with infiltration of inflammatory cells (fig.7,8). spleen showed hemorrhagic area degenerative of epithelial cells, also hemosidrosis and fibrosis(fig.9,10).

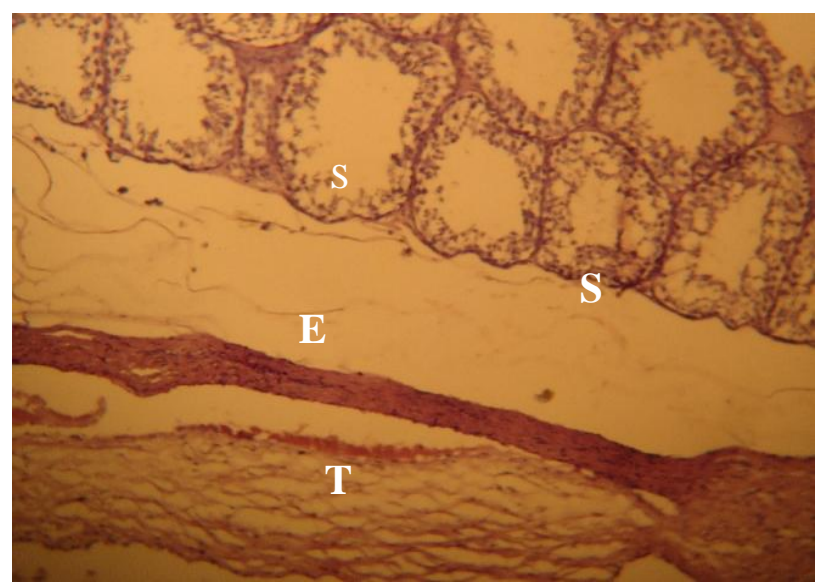

Figure capsul

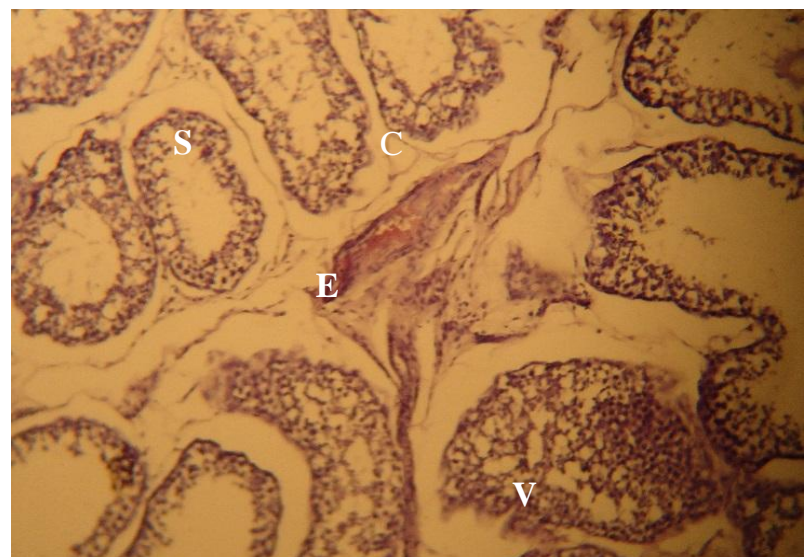

Figure (2):Testis, vacoulation of somniferous tubules cells $(\mathrm{V})$, interstitial edema(E), congestion of blood vessels

(C),and suppression of somniferous tubules cells (S).H\&E.10x . 


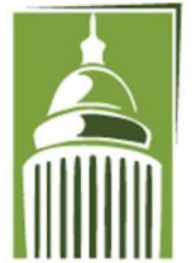

AR F

\section{Global Proceedings Repository \\ American Research Foundation}

ISSN 2476-017X
شبكة المؤتمات العربية

http://arab.kmshare.net/

Available online at http://proceedings.sriweb.org

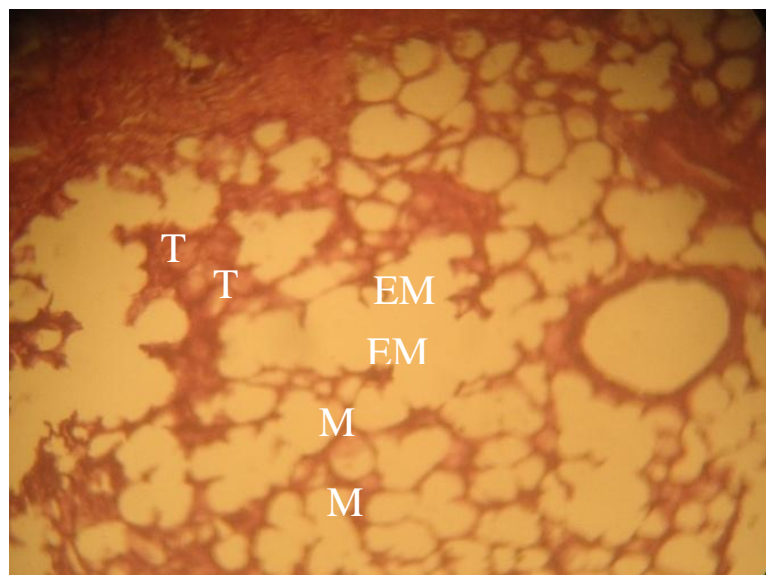

Figure (3): lung showed emphysema of alveoli(EM) thickening of alveolar wall $(\mathrm{T})$ with mucinous exudates( M).H\&E stain.10x

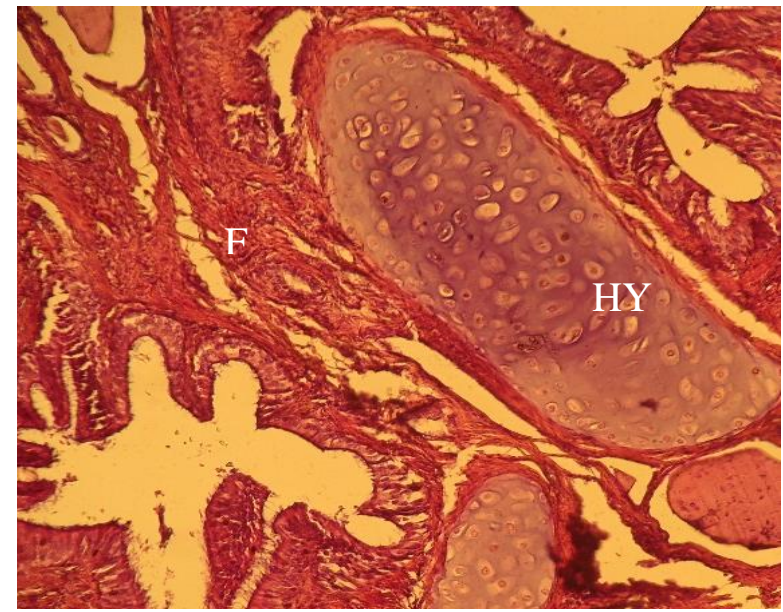

Figure (4): lung showed fibrosis in alveolar wall (F) and bronchus wall and hyperplasia of bronchus epithelial cells (HY) .H\&E stain.10x. 


\section{Global Proceedings Repository \\ American Research Foundation}

ISSN 2476-017X
شبكة المؤرمرات العربية

http://arab.kmshare.net/

Available online at http://proceedings.sriweb.org

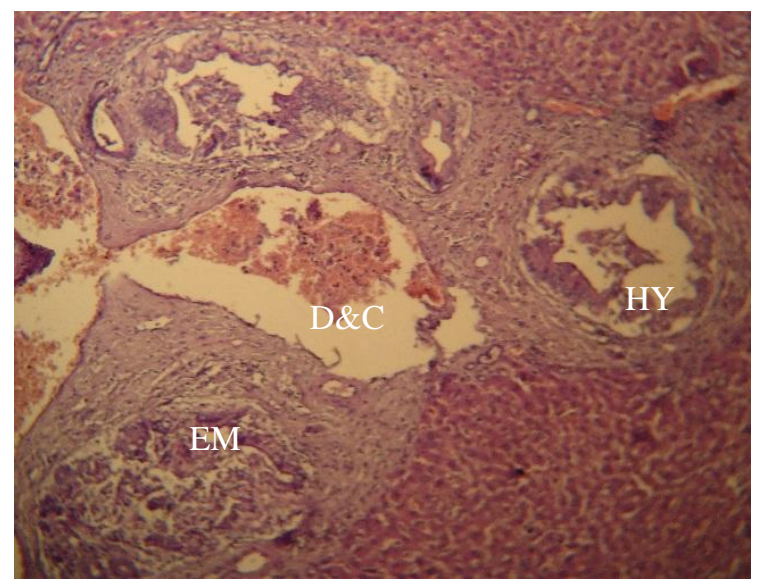

Figure(5): section of liver showed dilation (D)and

congestion (C) of hepatic duct, excessive fibrosis in portal area ,narrowing the lumen of portal duct $(\mathrm{N})$,hyperplasia of epithelial lining (HY). H\&E.40x

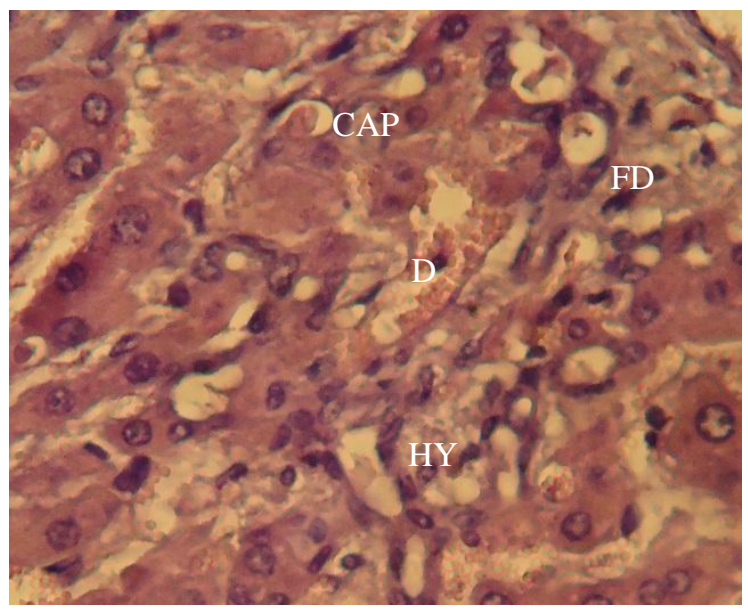

Figure(6): section of showed liver dilated of sinusoid (D),sub capsular fatty degeneration (FD),hypertrophy , hepatic cells (HY),new capillaries formation (CAP). H\&E.40x 


\section{Global Proceedings Repository \\ American Research Foundation}

ISSN 2476-017X

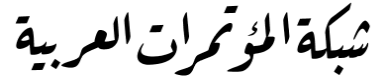

http://arab.kmshare.net/

Available online at http://proceedings.sriweb.org

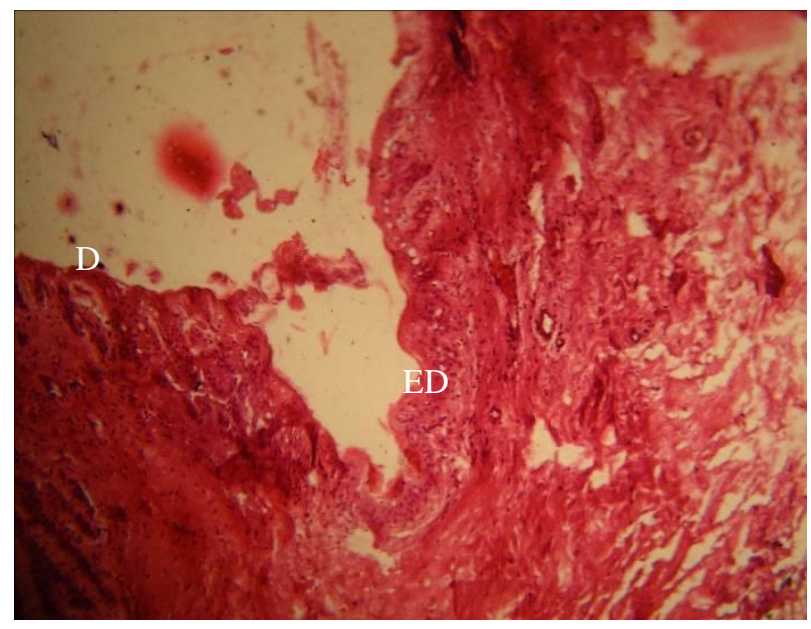

Figure(7): section of rumen showed degenerative changes of epithelial cells D, and edematous fluid (ED). H\&E stain.10x

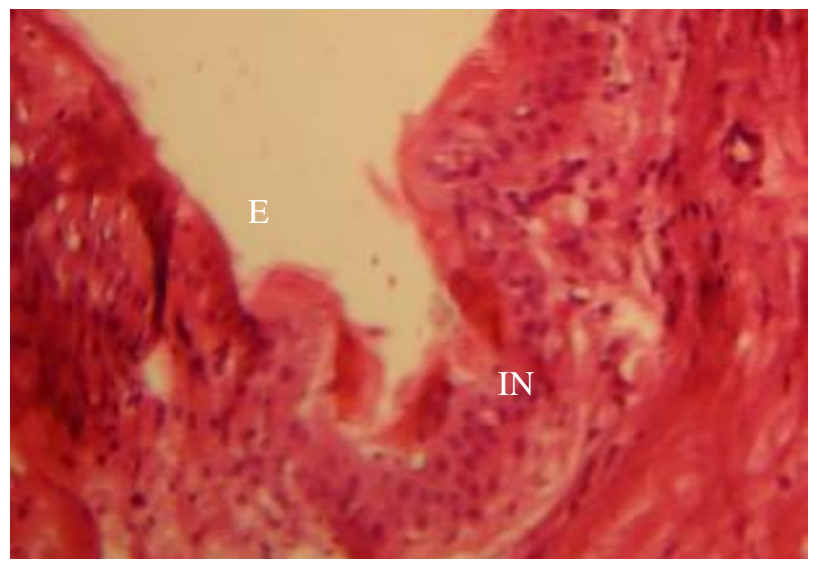

Figure(8): section of rumen showed erosion of epithelial cells (E), infiltration of inflammatory cells(IN), H\&E stain. $40 \mathrm{x}$ 


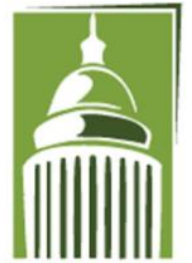

A R F

\section{Global Proceedings Repository American Research Foundation}

ISSN 2476-017X

Available online at http://proceedings.sriweb.org
شبكة المؤتمرات العربية

http://arab.kmshare.net/

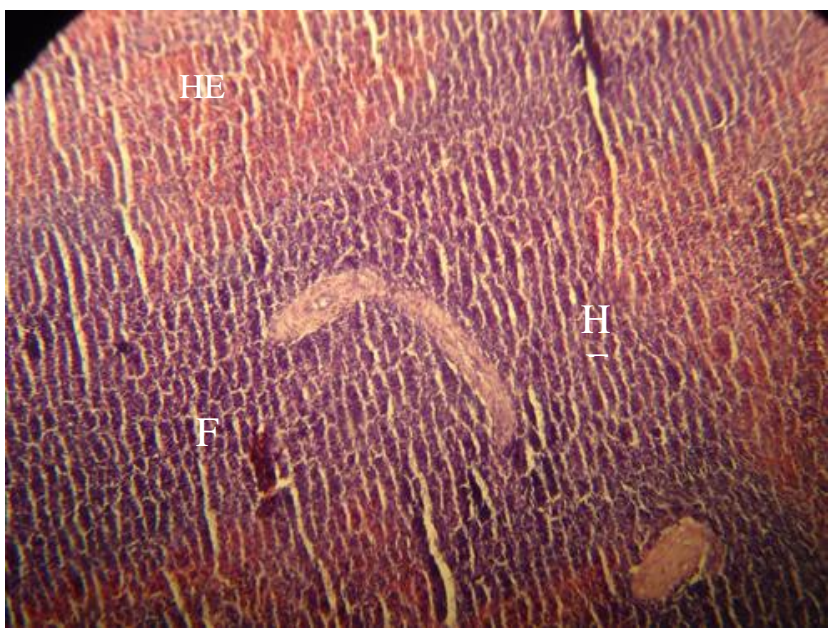

Figure(9): section of spleen showed hemorrhagic area degenerative of epithelial cells, H\&E stain.10x

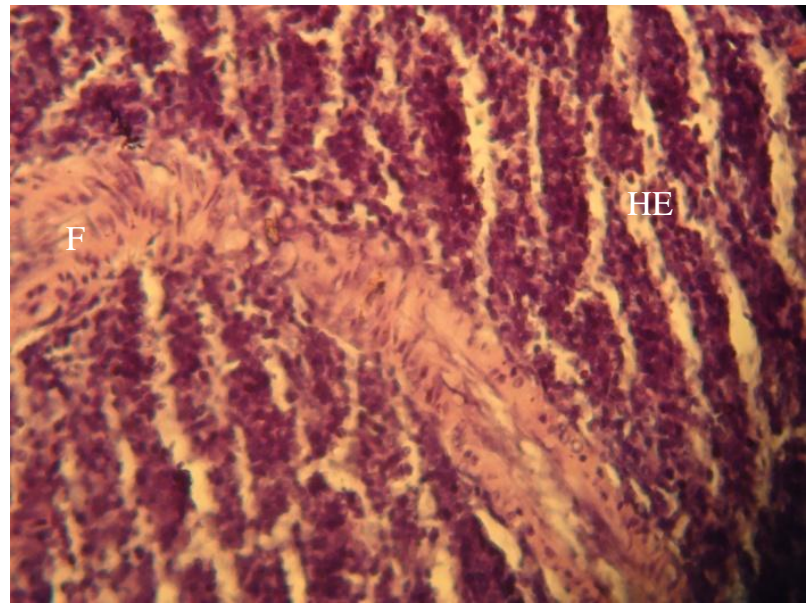

Figure(10): section of spleen showed hemosidrosis (HE) and fibrosis (F).H\&E stain.40x 


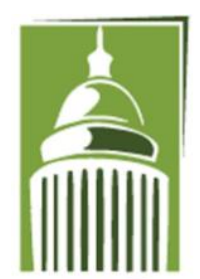

ARF

\section{Global Proceedings Repository \\ American Research Foundation}

ISSN 2476-017X

Available online at http://proceedings.sriweb.org

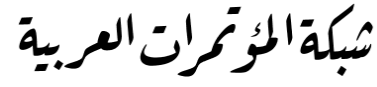

http://arab.kmshare.net/

\section{Discussion:}

In the present study goats were given bythe oral route phenobarbital only at $65 \mathrm{mg} / \mathrm{kg} / \mathrm{day}$ for 90days.showed liver enlargement and increased its weights indicating the presence of hepatomegaly, The increased weights were consistent with data from microscopic examination of the liver showing edema and compound related Centro lobular hepatocyte hypertrophy in deranged goats. These observations are in agreement with the findings were described by other researches [14\&15].

This study tested several hypotheses about the effects of Phenobarbital on liver regeneration, testes and pancrease due to the androgen sensitive. Reproductive organs of treated animals suffering from suppression of spermatogenesis through the effect of Phenobarbital such as necrosis of the testicular cells that agree with [16].vacuolated in testes and pancreas which are well supported with biochemical and enzymatical studies that provide the effect of phenobarbital that agree with [17].there were seen acute passive congestion is seen in spleen due to distention of red pulp by blood, the lymphoid tissues (periarteriolar lymphoid sheathes and splenic follicles are widely separated and replacement by fat tissue or connective tissues, various exogenous and endogenous stimuli lead to activate acute inflammation and then chronic inflammation in the body in which the tissue response consists of theleakage or accumulation of fluid into epithelial cells as response in intestine, rumen and pancrease[18\&19] .

\section{References:}

1.Kwan, P. and Brodie,M.I. (2004). Phenobarbital for the treatment of epilepcy in the 21 century.Acritical review Epilepsis 45(9): 1141-1149.

2.Anonymous1(2007).Http://www.canine-epilepsy-guardianangels.com/Phenobarbital.

3.Michelle ,M. (2007). The FDA Takes action against unapproved Drugs

" (http://permanent.access.gpo.gov/IPS 1609/www-fda.gov./fdac/featurs/2007/107 drug.html) . FDA consumer magazine. http://permanent access. Gpo.gov/IPS/609/www.fda.gov/fdacl features/2007/107.drug.html

4. Demir,O.E., VYazar,M.Altunok and VE.Ozdemir(2001). Effectof phenobarbital onantioxidant enzymeactivities andblood gas parameters in Balb/Cmice. Revue.Med. Vet., 152: 723-726

5.Aniya,Y.,M.Shimgajiand A.Naito(1993).Increase in liver microsomal glutathione Stransferas activity by Phenobarbital treatment ofrats. Possible involvement ofoxidative activation via cytodyrone P 450. Biochm.Pharmcol., 46: 1741-1747.

6.Videla, L.A, AC. Aris, AP. Fuzaro, O.R. Koch and V.S.C. Jun-Queria, ( 2000). Prolonged Phenobarbital pretreatment abolishes the early oxidative stress component induction in the liver by acute lindaneintoxication. Toxicol.Lett.,115: 45-51.

7.Clement,J.G.,1983. Effect of pretreatment with sodium phenobarbital on the toxicity of somanin mice. Biochem. Pharmacol., 32: 1411-1415. 


\section{Global Proceedings Repository \\ American Research Foundation}

ISSN 2476-017X

Available online at http://proceedings.sriweb.org

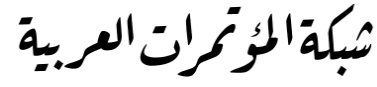

http://arab.kmshare.net/

A R F

8. Jump up; Kwan P; Brodie M.J. ( 2004). "Phenobarbital for the treatment of epilepsy in the 21st century: a critical review"

9 .Jump up; (2008)"Barbiturate intoxication and overdose", .MedLine Plus. Retrieved 15 July .

10. Jump up; Thomas, WB (2003). "Seizures and narcolepsy". In Dewey, Curtis W. (ed.). A Practical Guide to Canine and Feline Neurology. Ames, Iowa: Iowa State Press. ISBN 0-8138-1249-6.

11. Jump up^ Dodman, Nicholas.(2006). "Feline Hyperesthesia (FHS)" Practical Guide to Canine and Feline Neurology. Ames, Iowa: Iowa State Press.

12.Jump up^ Editor, Cynthia M. Kahn; associate editor Scott Line (February 8, 2005). Kahn, Cynthia M., Line, Scott, Aiello, Susan E. (ed.), ed. The Merck Veterinary Manual (9th ed.). John Wiley \& Sons. ISBN 0-911910-50-6.

13. Annpreece, H.T., 1972. A manual for histological Technicians. 3th Edn., Little Brown and Company.Boston, USA, pp: 428.

14.Meltzer, R.C.; Hoenig ,D.M. Chrostek,C. and Amaral,J.F. (1994). Porcine seromyotomies using an ultrasonically activated scalpel. Surg. Endosco. 8: 250-253.

15.Amaral, J.F. and Chrostek, C. (1995). Depth of thermal injury ultrasonically activated scalpel versus electrosurgery surg. Endosc: 9:229.

16. Dssense, A.B.; Cohen, K.P.; Gidon, J.M. and Kees, B.K. (2001). Association of prenatal Phenobarbital and phonation exposure with genital anomalies and menstrual disorders .J.Reader ship Survey,64(4):181188 .

17. Punt, N.; Shankar, R. and Srivastava,S.(2002). In uteri and Locational exposure of carbofuran to rats: effect on testes and perm.Hum.Exp.Toxicol.,21:37-41.

18.McGavin,M.D.; Zachary, J.F.(2007).Pathologic Basis of Veterinary Disease. Fourth edition, 447-460.w w w.elsevierhealth.com.

19. Ehsan, L. M ; Majeed, S. K ,Al-Fars A. A (20015). Toxicologic Pathology Effect Of Phenobarbital In PartiallyHepatectomized In Goats .Journal Of International Academic Research For Multidisciplinary ,Impact Factor 1.625, Issn: 2320-5083, Volume 3, Issue 1, February 2015. 